\title{
Trade in African Rhino Horn
}

\section{S. C. Parker and Esmond Bradley Martin}

Between 1969 and 1976 the price of rhino horn in Kenya rose 446 per cent - from K£8.24 per kilogram to $K_{£ 44.6}$. Between 1972 and 1976 the average amount exported each year represented the product of 1197 rhinos. Most of it went to Hong Kong, but demand was rising in southern Arabia, especially North Yemen. In March 1979 rhino horn imports were totally banned in Hong Kong, but the authors believe that the price in North Yemen will continue to rise, and with it the demand for rhino horn.

Over the past ten years we have been collecting data on the international trade in rhino horn originating in East Africa. These are of some interest in view of the current concern about the black rhino Diceros bicornis (see page 131), on whose status in the wild there is little published data.

\section{Methods and Results}

Information on the quantities and value of rhino horn exports was collected from the Annual Reports of the Game Department of the then Uganda Protectorate (1936-1948), the Blue Books for Uganda, Tanganyika and Kenya (1926-1948), and the former East African Customs and Excise Department's Annual Reports for the three East African countries (1949-1976). In addition, we have obtained data on rhino-horn imports to the North Yemen from the Annual Reports of the Central Bank of Yemen from 1971 to 1977.

Our results are presented in the three tables and two graphs. Tables 1 and 2 show the total East African rhino-horn exports, in quantities and value from 1926 to 1976. The two graphs show the export trends. Table 3 shows the quantities and value of rhino horn arriving in North Yemen. For reasons of space, a table showing to which countries the horn was exported, together with quantities and value, is summarised at the end of this article and can be had on application to the FPS office or the authors.

\section{Discussion}

The data indicate that there were few rhinos in Uganda in the period covered. From personal recollections of one of us (ISCP) much of the rhino horn attributed to Uganda originated from white rhino Ceratotherium simum in the southern Sudan or north-eastern Zaire and was seized in illicit transit through Uganda or Kenya.

The Kenya and Tanzania data are similar between 1926 and 1958, both in amounts and patterns. Both show depressions during the $1939-45$ war years and major peaks in 1946, the obvious explanation being that stocks accumulated during the war when exports were difficult and were released in a flood when communications were restored. After 1958 the Tanzania data suggest progressive declines, whereas the Kenya figures denote an increase. We do not know of any official explanation of the eight tons exported from Kenya in 1972 - some 695 per cent above the previous ten-year average - although in part it 
Table 1 East African Domestic Rhino Horn Exports in Kg, 1926 - 1976

\begin{tabular}{|c|c|c|c|c|}
\hline Year & Kenya & Uganda & Tanzania & Total \\
\hline $\begin{array}{r}1926 \\
7\end{array}$ & $\begin{array}{l}965 \\
864\end{array}$ & & & \\
\hline 8 & 711 & & & \\
\hline 9 & 610 & & 1,931 & \\
\hline 1930 & 1,372 & 1,321 & 864 & 3,557 \\
\hline 1 & 406 & - & 457 & 863 \\
\hline 2 & 559 & 102 & 1,219 & 1,880 \\
\hline 3 & 305 & - & 1,118 & 1,423 \\
\hline 4 & $1,219^{\circ}$ & 102 & 813 & 2,134 \\
\hline 1935 & 305 & 153 & 660 & 1,118 \\
\hline 6 & 1,219 & 153 & 457 & 1,829 \\
\hline 7 & 508 & 24 & 559 & 1,091 \\
\hline 8 & 305 & 48 & 508 & 861 \\
\hline 9 & 660 & 38 & 508 & 1,206 \\
\hline 1940 & 250 & 56 & 711 & 1,017 \\
\hline 1 & 203 & 20 & 356 & 579 \\
\hline 2 & 0 & 7 & 152 & 159 \\
\hline 3 & 0 & 33 & 0 & 33 \\
\hline 4 & 457 & 21 & 406 & 884 \\
\hline 1945 & 0 & 41 & 0 & 41 \\
\hline 6 & 3,506 & 11 & 2,134 & 5,651 \\
\hline 7 & 1,307 & 17 & 965 & 2,289 \\
\hline 8 & 2,319 & 23 & 508 & 2,850 \\
\hline 9 & 762 & - & 1,016 & 1,778 \\
\hline 1950 & 1,473 & 51 & 1,016 & 2,540 \\
\hline 1 & 965 & 51 & 559 & 1,575 \\
\hline 2 & 610 & - & 254 & 864 \\
\hline 3 & 559 & - & 813 & 1,372 \\
\hline 4 & 660 & - & 1,524 & 2,184 \\
\hline 1955 & 1,089 & 45 & 1,361 & 2,495 \\
\hline 6 & 1,134 & 136 & 862 & 2,132 \\
\hline 7 & 907 & - & 1,089 & 1,996 \\
\hline 8 & 953 & 45 & 544 & 1,542 \\
\hline 9 & 726 & 45 & 363 & 1,134 \\
\hline 1960 & 1,179 & - & 181 & 1,360 \\
\hline 1 & 408 & 0 & 272 & 680 \\
\hline 2 & 1,678 & 272 & 499 & 2,449 \\
\hline 3 & 1,225 & - & 590 & 1,815 \\
\hline 4 & 814 & 0 & 218 & 1,032 \\
\hline 1965 & 726 & 94 & 203 & 1,023 \\
\hline 6 & 508 & 5 & 221 & 734 \\
\hline 7 & 1,280 & 60 & 615 & 1,955 \\
\hline 8 & 601 & 125 & 403 & 1,129 \\
\hline 9 & 1,133 & 27 & 285 & 1,445 \\
\hline 1970 & 1,093 & 12 & 105 & 1,210 \\
\hline 1 & 1,472 & 13 & 199 & 1,684 \\
\hline 2 & 8,371 & 0 & 18 & 8,389 \\
\hline 3 & 3,182 & 18 & 12 & 3,212 \\
\hline 4 & 838 & 0 & 0 & 838 \\
\hline 1975 & 4,783 & 0 & 0 & 4,783 \\
\hline 6 & 3,339 & 0 & 386 & 3,725 \\
\hline
\end{tabular}

* Before 1964 Tanganyika only 
Table 2 East African Domestic Rhino Horn

\begin{tabular}{|c|c|c|c|c|}
\hline Year & Kenya & Uganda & Tanzania & Total \\
\hline 7 & $\begin{array}{l}2,323 \\
3,371\end{array}$ & & & \\
\hline 8 & 2,956 & & & \\
\hline 9 & 2,854 & & 6,957 & \\
\hline 1930 & 1,725 & 1,619 & 1,372 & 4,716 \\
\hline 1 & 531 & 30 & 578 & 1,139 \\
\hline 2 & 937 & 164 & 2,261 & 3,362 \\
\hline 3 & 676 & 98 & 1,829 & 2,603 \\
\hline 4 & 1,534 & 97 & 1,018 & 2,649 \\
\hline 1935 & 551 & 232 & 750 & 1,533 \\
\hline 6 & 1,876 & 249 & 657 & 2,782 \\
\hline 7 & 932 & & 1,012 & \\
\hline 8 & 644 & & 894 & \\
\hline 9 & 1,195 & & 960 & \\
\hline 1940 & 448 & 88 & 1,320 & 1,856 \\
\hline 1 & 502 & 50 & 767 & 1,319 \\
\hline 2 & 15 & 12 & 190 & 217 \\
\hline 3 & 0 & 52 & 0 & 52 \\
\hline 4 & 747 & 30 & 511 & 1,288 \\
\hline 1945 & 0 & 87 & 0 & 87 \\
\hline 6 & $284(?)$ & 51 & 5,950 & \\
\hline 7 & 2,680 & 37 & 2,681 & 5,398 \\
\hline 8 & 4,926 & 52 & 996 & 5,974 \\
\hline 9 & 1,355 & 9 & 2,440 & 3,804 \\
\hline 1950 & 4,630 & 226 & 3,207 & 8,063 \\
\hline 1 & 4,898 & 304 & 2,554 & 7,756 \\
\hline 2 & 3,697 & 65 & 2,141 & 5,903 \\
\hline 3 & 4,651 & 146 & 5,393 & 10,190 \\
\hline 4 & 4,898 & 243 & 7,722 & 12,863 \\
\hline 1955 & 7,002 & 440 & 12,434 & 19,876 \\
\hline 6 & 7,844 & 1,204 & 7,335 & 16,383 \\
\hline 7 & 7,513 & 47 & 8,177 & 15,737 \\
\hline 8 & 9,974 & 315 & 6,884 & 17,173 \\
\hline 9 & 7,417 & 406 & 3,852 & 11,675 \\
\hline 1960 & 12,398 & 171 & 3,053 & 15,622 \\
\hline 1 & 3,729 & 0 & 2,109 & 5,838 \\
\hline 2 & 12,610 & 1,783 & 3,224 & 17,617 \\
\hline 3 & 7,485 & 131 & 3,683 & 11,299 \\
\hline 4 & 5,739 & 0 & 1,438 & 7,177 \\
\hline 1965 & 7,333 & 936 & 1,661 & 9,930 \\
\hline 6 & 4,328 & 28 & 1,850 & 6,206 \\
\hline 7 & 11,290 & 560 & 4,946 & 16,796 \\
\hline 8 & 5,770 & 925 & 3,411 & 10,106 \\
\hline 9 & 9,336 & 179 & 2,321 & 11,836 \\
\hline 1970 & 10,602 & 77 & 811 & 11,490 \\
\hline 1 & 22,416 & 183 & 2,470 & 25,069 \\
\hline 2 & 59,537 & 0 & 156 & 59,693 \\
\hline 3 & 53,640 & 275 & 183 & 54,098 \\
\hline 4 & 9,285 & 0 & 0 & 9,285 \\
\hline 1975 & 55,657 & 0 & 0 & 55,657 \\
\hline 6 & 149,081 & 0 & 6,820 & 155,901 \\
\hline
\end{tabular}

*Before 1964 Tanganyika only 

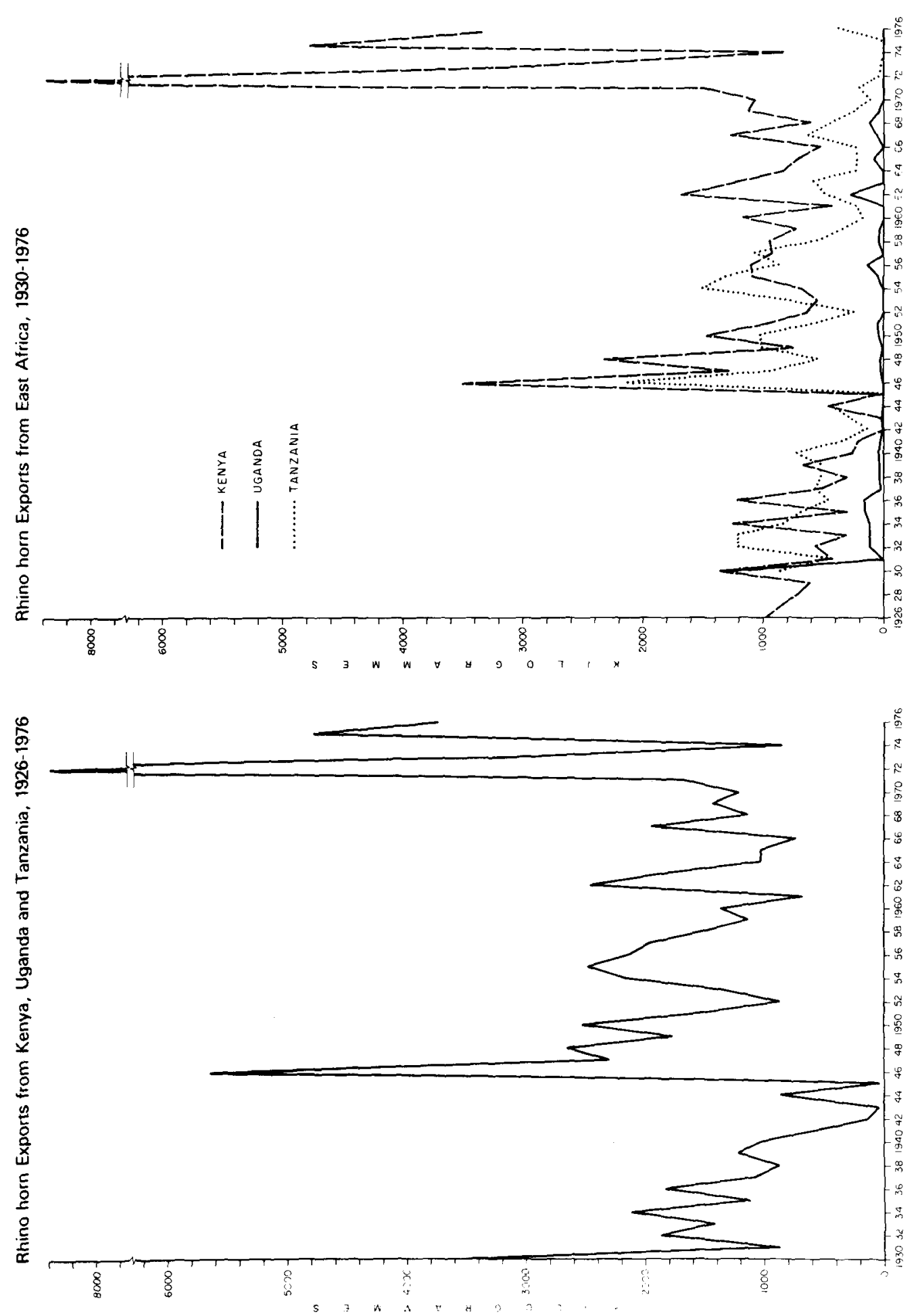
Table 3 Rhino Horn Imported into North Yemen 1969 - 1977

$\begin{array}{lr}\text { Year } & \text { Amount } / \mathrm{kg} \\ 1969-70 & 233 \\ 1970-71 & 131 \\ 1971-72 & 1445 \\ 1972-73 & 2139 \\ 1973-74 & 3544 \\ 1974-75 & \text { nil } \\ 1975-76 & 8310 \\ 1976.77 & 6843 \\ 1969-77 & 22645\end{array}$

from the Annual Reports of the Central Bank of Yemen 1971-1977.

may have been accounted for by many rhino deaths during the serious drought in eastern Kenya the year before. The general trend of increasing rhino-horn exports would be in response to the sharp rise in prices from $\mathrm{K} £ 8.24$ per $\mathrm{kg}$ in 1969 to $\mathrm{K} £ 44.6$ per $\mathrm{kg}$ in 1976 - 441 per cent.

Our data show minimum rhino mortality because they come from official figures and therefore do not reveal illegal kills. Confidential information given to one of us (ISCP) in the course of research into the ivory trade confirms that from Kenya illegal rhino-horn exports have always exceeded legal exports. Taking East Africa as a whole - Kenya, Tanzania and Uganda - the average annual number of rhino represented by the export statistics was 563 between 1930 and 1934, and 1197 between 1972 and 1976 (based on an estimate of $3.5 \mathrm{~kg}$ of horn per animal).

Over the period 1949-1976, Hong Kong has been the major import market for rhino horn (as shown in the table summarised but not published here), but southern Arabian countries - Aden (South Yemen) and North Yemen - have taken an increasing share of the market. Table 3 confirms this trend of a rising demand in North Yemen imports between 1969 and 1977. There are several reasons for this. The annual per capita income in North Yemen has increased from $\$ 80$ in 1970 to $\$ 500$ in 1978 , due to the large number of Yemenis working in Saudi Arabia; in 1978, one million Yemenis working abroad remitted $\$ 1500$ million to North Yemen. Every male above adolescence must own a jambia (dagger), and those most in demand have rhino-horn handles. One of us (EBM) saw the horn being carved into handles in the main market in Sana'a, and established that one wholesaler supplied most of the horn; the price in late 1978 was $\$ 675$ per $\mathrm{kg}$.

In late 1978 ISCP examined import data in Hong Kong which indicated that few rhino horns had entered in the preceding tive months, the greatest single shipment being $1000 \mathrm{~kg}$ of chippings and shavings from Southern Arabia. Hong Kong traders said that the Yemeni prices were too high for them. Since then the Hong Kong traders have recommended, as a conservation measure, a total ban on rhino-horn imports into the colony. Their recommendation was accepted by the government and became law in March 1979. Thus the colony is no longer a market for legal rhino horn.

We have been told that in much of southern and south-east Asia rhino horn is used for medicinal purposes. This is so in two Indian states, Gujerat and Bengal. 
In Gujerat EBM was told that in 1978 demand was being met by illegal East African exports at $\$ 375$ per $\mathrm{kg}$. The Bengalis have no traditional trading connection with East Africa and try to get supplies from Indian rhinos killed in neighbouring Assam, for which they pay $\$ 875$ per $\mathrm{kg}$.

\section{Conclusion}

From our data and collected information we believe that, in the absence of unforeseen political events in the Arabian peninsula, the price of rhino horn will continue to rise and provide yet greater incentive to hunt rhinos of all species for their horns.

\section{Summary of Import Statistics}

Customs figures from the three exporting countries show that from 1949 to 1976 Hong Kong imported $23,852 \mathrm{~kg}$ of rhino horn, roughly two-fifths of total exports $-57,175 \mathrm{~kg}$. The other major primary importers were Aden/South Yemen, $8857 \mathrm{~kg}$; mainland China, $7619 \mathrm{~kg}$; USA, 2723kg; Japan, 1639kg; UK, 1549kg; Zambia, 907kg; and West Germany, $124 \mathrm{~kg}$. From 1949 until 1964, when it joined with Tanganyika to form Tanzania, Zanzibar imported $7192 \mathrm{~kg}$. China, the third largest customer for the entire 28 -year period, did not begin importing at all until 1968, and in 1972 bought $4554 \mathrm{~kg}$, more than any other country in any one year. Minor importers were Argentina, Australia, Austria, Bahrain, Belgium, Brazil, Canada, Denmark, Egypt, Finland, France, India, Iran, Italy, Malaya (pre-Malaysia), Mozambique, Netherlands, New Zealand, Norway, Rhodesia and Nyasaland, Saudi Arabia, Singapore, South Africa, Spain, Sri Lanka, Sweden, Switzerland, Syria and I.ebanon. Thailand, and Uruguay. General categories in the statistics include Central and South America (37.5kg) and 'other' $(2130.5 \mathrm{~kg})$. In many instances the amount imported by a particular country was considered negligible, listed as 'trace', and not reckoned in the final sums. A complete table of import statistics for 1949-1976 is obtainable from the FPS office.

I.S.C. Parker, PO Box 30678, Nairobi, Kenya.

Dr Esmond Bradley Martin, PO Box 15510, Mbagathi, Nairobi, Kenya.

\section{Fur and Skin Smuggling}

According to ISPA News in a period of 18 months a fur-smuggling operation in the USA was responsible for traffic in 46,000 margays, 30,000 ocelots, 15,500 otters, 5600 leopards, 1900 cheetahs, 500 pumas and 200 aguars, representing nearly 100,000 animals. The value of the shipments was some $\$ 5$ million. A report by ISPA investigators on traffic in South American wildlife says that in one month more than 30,000 caiman skins entered Suriname from Brazil. In another month, 7700 lizard and more than 4000 snake skins arrived for trans-shipment. In 1978 approximately 13 tons of deer skins and 12.5 tons of peccary skins were shipped through Suriname.

\section{Effect of Elephants in the Akagera Park}

In 1975 the Rwandese Government decided that a population of 134 elephants in central Rwanda were so troublesome that they must be eliminated. As part of the operation 26 young elephants (from one to 12 years old) were transported and released in the Akagera National Park, in the north-east, where there were no elephants. Although they belonged to different family units, the young elephants formed stable social herds in their new habitat, according to a report by Nicole and Alain Monfort in La Terre et la Vie $(1979,1)$, and their presence appears to be beneficial for most of the grazing animals; for the smaller ungulates particularly, they open up the vegetation making more food available. 